\title{
Integrating Competence-Based Assessment into Instruction Pedagogical Subjects for Developing Core Competences of Technical and Vocational Education Students at Ho Chi Minh City University of Technology and Education
}

\author{
Oanh. Duong Thi Kim \\ Institute of Technical Education, Ho Chi Minh City University of Technology and Education, Vietnam
}

Received August 19, 2019; Revised September 9, 2019; Accepted September 22, 2019

Copyright $(2019$ by authors, all rights reserved. Authors agree that this article remains permanently open access under the terms of the Creative Commons Attribution License 4.0 International License

\begin{abstract}
With the tendency of shifting from Knowledge-Based Education into Competence-Based Education, assessment is not only of learning but also for and as learning. In Competence-Based Education, Competence-Based Assessment (CBA) is a process of collecting evidence and making judgments on whether competence has been achieved and regulating teaching and learning activities. Integrating CBA into instruction provides students with opportunities to self-construct their competences by applying academic knowledge to solve assessment tasks well related to real-world contexts. This paper referred to international discussions on the term of CBA, the meaning of integrating CBA into instruction and proposing a process of integrating $\mathrm{CBA}$ into instruction Pedagogical subjects for developing core competences of students. This paper also analyzed the development of Problem-Solving Competence and Presentation Competence of 33 Food Technology Education students and 22 Garment Technology Education students after dealing with the assessment tasks integrated into instruction General Psychology and Vocational Education subjects and presenting the results at Ho Chi Minh City University of Technology and Education. Finally, some minor suggestions for developing core competences of Technical and Vocational Education students through integrating CBA into Instruction Pedagogical subjects by carefully considering the consistency of course learning outcomes, teaching-learning activities and assessment were discussed.
\end{abstract}

Keywords Competence-Based Assessment, Core Competence, Pedagogical Competence, Assessment Task

\section{Introduction}

Together with learning outcomes, content and instruction, assessment is one of the key components of a teaching process. With the shift from Knowledge-Based Education (focus on knowledge) (KBE) to Competence-Based Education (focus on competences) (CBE), assessment is not only used to assess learning but also for and as learning. In the CBE, Competence-Based Assessment (CBA) is a process of collecting evidence and making judgments on whether competence has been achieved. Not only does CBA provide students with evidence to recognize which their own knowledge, skills and attitudes have been attained, but also CBA is even used to regulate teaching and learning activities.

Despite instruction engages closely with assessment in the teaching process, but they are considerable detached each other in the KBE. Collecting evidence and making judgments on whether competence has been achieved often take place throughout the entire teaching - learning process. So, the integration CBA into instruction enhances a variety of Competence-Based Teaching methods in each lesson as well as enables students to hands-on and experience to self-construct their knowledge, skills and attitudes or means their own competences.

To integrate CBA into instruction Pedagogical subjects for developing core competences (problem-solving and presentation) of Technical and Vocational Education students at Ho Chi Minh City University of Technology 
and Education (HCMUTE), this paper refers to international discussions on the term of $\mathrm{CBA}$ and the meaning of integrating CBA into instruction as well as proposes a process of integrating CBA into instruction Pedagogical subjects. On the other hand, an improvement of core competences of Technical and Vocational Education students after integrating CBA into instruction General Psychology and Vocational Education subject is also analyzed in more details.

\section{The International Discussion on the Term of Competence-Based Assessment and the Meaning of Integrating Competence-Based Assessment into Instruction}

A teaching process often comprises of components such as learning outcomes, contents, instruction, teaching aids and assessment. Although the assessment is placed at the end position of the teaching process, it is closely connected with the front components. Assessment is not only used to collect evidence of performances of students but also reflects the effectiveness of using teaching methods in the class.

Study on benefits of CBE for professional development, as stated by Cees P.M. van der Vleuten (2015:323): "Competency-based education is a logical next step in professionalizing education. A competency is the integration of knowledge, skills and attitudes to successfully engage with a professional task. Competency-based education is when a curriculum or training program provides holistic tasks to practice these competencies". CBE focuses on 'teach knowledge' or 'transfer knowledge' and emphasizes the development of holistic competence of students. Therefore, assessment in CBE needs to be shifted from "evaluate knowledge and skills" to "competence-based assessment".

As stated by Wolf (1995:1): "CBA is a form of assessment that is derived from the specification of a set of outcomes; that so clearly states both the outcomes - general and specific - that assessors, students and interested third parties can all make reasonably objective judgments with respect to student achievement or non-achievement of these outcomes; and that certifies student progress on the basis of demonstrated achievement of these outcomes. Assessments are not tied to time served in formal educational settings". Wolf suggested that assessors, students and third parties can understand what is being assessed, and what should be achieved based on the learning outcomes and professional standards.

With regard to the term CBA, Western Australia Department of Training and Workforce Development (2013:18) stated that: "CBA is the process of collecting evidence and making judgments on whether competence has been achieved. This confirms that an individual can perform to the standard expected in the workplace as expressed in the relevant endorsed industry/enterprise competency standards (or outcomes of accredited courses if there are no competency standards for an industry)".

This paper defines CBA as stated by Duong (2016: 3): "Competence-Based Assessment is an assessment approach based on learning outcomes (subjects or curriculum) or professional standards to make judgments on whether competence has been achieved through evidence associated with flexible application of knowledge, skills, attitudes, values and personal attributes such as motives, interests, needs, beliefs and so on in dealing with real-world problems".

There is a strong shift in emphasis from isolating assessment and instruction towards integrating assessment into instruction as stated by William (2004:16) that: "Perhaps one day we will not talk about "integrating instruction with assessment" because the distinction between the two will be meaningless". This integration provides teachers and students with valuable feedbacks to regulate teaching and learning activities and gives suggestions how the lesson could be improved.

Study on developing and using classroom assessment, Oosterhof (2003:198) believed that educational reform efforts tend to emphasize the importance of integrating assessment into instruction. Knowledge should be instructed and assessed simultaneously. Integration assessment into instruction within a cognitive approach helps learners become an expert and within a constructivist approach helps learners construct new knowledge.

Sesutho Koketso Kesianye (2015: 213 - 214) indicated three main potential benefits of the integration assessment into instruction for learning mathematics:

- Matching of what is taught to what is assessed has great potential for enhancing learning.

- Teachers are capable of finding out how their teaching impacts on learning.

- The gap between instruction and learning is shorten through bringing together the teacher and students to be both responsible for learning.

Integrating assessment into the lesson plan to improve learning, Elui (2008) indicated the primary aim of assessment is to improve the learning of worthwhile academic content for all the pupils. Assessment, as a part and parcel of teaching can help a teacher to determine how well he/she is meeting instructional goals and how to adjust curriculum and instruction so that the goals will be better achieved. Elui also analyzed five techniques for effective integration of assessment into the lesson plan, including Effective Planning, Learning Experience Approach/Participatory Learning, Balance between Process and Product Evaluation, Systematic Periodic Testing and Follow through.

Analyzing the European Higher Education Area-Driven Educational Innovation, $\mathrm{M}^{\mathrm{a}}$ Asunción Romero López 
stated that, the improvement of quality in Higher Education is undergoing a change in both the pedagogical process and its assessment. Assessment is an essential component of the teaching-learning process, both to ensure that learning is achieved and to orient the methods of its acquisition properly, permitting improvement of the quality of learning. Assessment activities should thus be consistent with the learning process and methodology followed (lectures, case method, problem-based learning, cooperative groups, project work, seminars, tutorials, etc.) and refer to the application of knowledge in real -world contexts.

In short, CBA has been drawn international researchers' attention since the final decade of the 20th century. Assessment has been separated from the other components of the teaching process and only used to make judgments of learning, not for and as learning in the "Knowledge-Based Education". Therefore, integrating CBA into instruction could be more relevant to the tendency of shifting from "focus on knowledge" to "focus on competence" at Universities of Technology and Education in Vietnam.

\section{Propose the Process of Integrating Competence-Based Assessment into Instruction Pedagogical Subjects at Ho Chi Minh City University of Technology and Education}

The Industrial Revolution 4.0 challenges a massive transformation in employee competences and training. New competences have been built upon the foundation of core competencies - including literacy, numeracy, communication, teamwork and problem solving. Core competencies are personal attributes or underlining characteristics, which combined with technical or professional competences, enable the delivery of a role/job
(OECD, 2014).

The requirements for the quality of technicians and workers resources to adapt with the Industrial revolution 4.0 are urging Universities of Technology and Education in Vietnam to switch from the KBE to the CBE. Universities of Technology and Education are main responsible for training Technical and Vocational Students to become Technical and Vocational Teachers those are not only good at technical knowledge and skills but also adept at pedagogical and core competences. Thus, in addition to specialized technical subjects, Pedagogical subjects such as General Psychology, Vocational Education, Teaching Theory, Curriculum Development and so on are also embedded in the academic program of Technical and Vocational Education.

To help students develop their core competencies, Competence-Based Teaching methods such as group-work, problem-based learning, project-based learning, situation-based learning etc. needs to be combined flexibly. These teaching methods encourage students to explore, look into, debate, learn by doing, hands-on and apply academic knowledge into divergent real-world and professional contexts in a collaborative learning environment. On the other hand, they also provide students with opportunities to to learn more deeply to develop holistic competences.

CBA engages tightly with Competence-Based Instruction to collect evidence on competences of students. Assessment tasks are typical forms of CBA. Assessment tasks should be clearly aligned with the learning outcomes, teaching and learning activities as stated by the Learning and Teaching Centre at Macquarie University. There are many types of assessment tasks embedded in instruction including essay, performance report, project, presentation, poster, self-assessment, peer-assessment. This paper proposed a process of integrating CBA into instruction Pedagogical subjects at HCMUTE in the below section: 


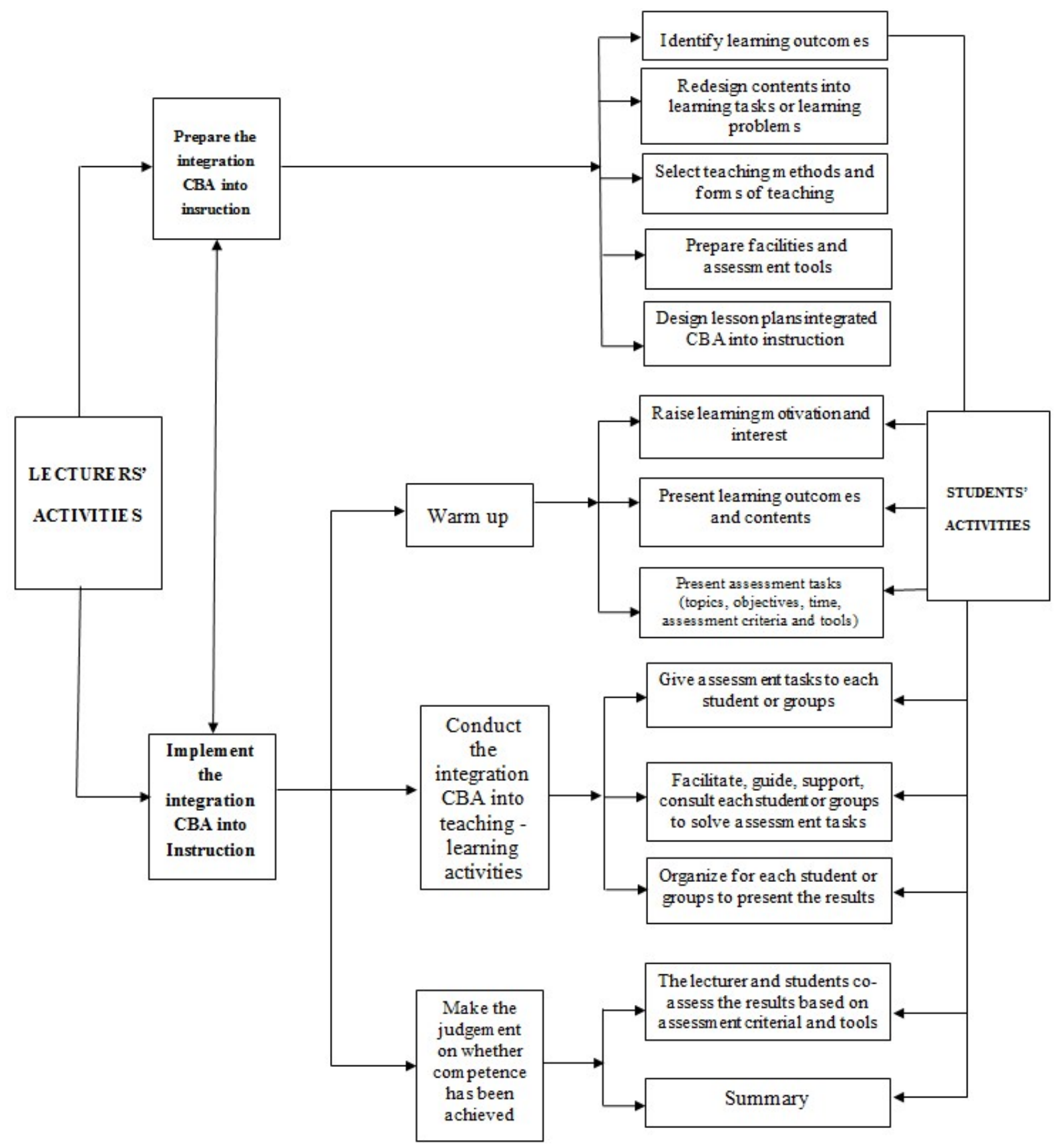

Figure 1. Process of integrating CBA into Instruction Pedagogical subjects

To integrate CBA into Instruction Pedagogical subjects, two stages should be followed:

\section{Stage 1: PREPARE THE INTEGRATION CBA INTO INSTRUCTION}

The integration CBA into instruction links closely with all components of the teaching process. So, integrating CBA into instruction requires well-prepared through the following activities:

- Identify learning outcomes of a lesson/a chapter of each subject. The learning outcomes of Pedagogical subjects do not only describe the knowledge, skills or attitudes as competences that students should acquire by the end of a lesson/a chapter of each subject but also guide assessment.

- Restructure contents into learning tasks/problems or learning projects which are fundamental elements of Competence-Based Assessment tasks.

- Select Competence-Based Teaching methods and forms of teaching to be relevant to learning outcomes and assessment tasks.

- Design lesson plans integrated assessment tasks into instruction in correlation with components of the teaching process. A lesson plan is the lecturer's road map of what students need to learn and how it will be done effectively during the class time. Appropriate 
learning activities and strategies for assessing and giving feedback on student learning are embedded in a lesson plan.

- Prepare facilities and assessment tools.

\section{Stage 2: IMPLEMENT THE INTEGRATION CBA INTO INSTRUCTION}

There are three steps with many specific activities to implement the integration CBA into instruction as bellows:

\section{Step 1: Warm up}

Starting the lesson with warm up activities will captivate the students and draw them into the lesson. The lecturer starts the lesson by doing the following activities:

- Raise leaning motivation through placing students in front of real-world or professional issues which require students to apply academic knowledge of the lesson to tackle them.

- Present learning outcomes to direct students to pay attention to the knowledge, skills or attitudes that students should acquire by the end of the lesson.

- Present assessment tasks with topics, objectives of assessment tasks, assessment criteria and tools to draw students' concerns to the lesson.

Step 2: Conduct the integration CBA into teaching learning activities

The integration CBA into teaching-learning activities is implemented as follows:

- Give assessment tasks to each student or groups (form groups of 4 - 6 students). Assessment tasks should be explained precisely and clearly. Assessment criteria and tools are informed to students.

- $\quad$ Facilitate, make directed questions, support or consult each student or groups to deal with assessment tasks during the entire teaching process.

- Organize for individuals or groups to present results.

Step 3: Make the judgements on whether students' competences have been achieved

The lecturer and students co-assess the results based on assessment criteria and tools embedded in Rubrics. Rubrics give the lecturers quantitative and qualitative evidence to make the judgements on whether students' competences have been achieved.

Finally, the lecturer summaries which the knowledge, skills or attitudes as competences that students have acquired at end of a lesson/a chapter of each subject.

To sum up, respecting the idea that integrating CBA into instruction could be more relevant to the trend of shifting from "focus on knowledge" to "focus on competence" to develop students' competence, this paper suggests the process of integrating CBA into instruction Pedagogical subjects with two-coherent stages and the specific teaching - learning activities. This process is suitable with the common competence-based teaching process.

\section{Developing Core Competences of Technical and Vocational Students through Integrating CBA into Instruction Pedagogical Subjects at Ho Chi Minh City University of Technology and Education}

Among pedagogical subjects of the academic program of Technical and Vocational Education, General Psychology and Vocational Education are fundamental subjects to equip students with main core competences (problem-solving, presentation), which combined with pedagogical competences (planning, selecting the appropriate teaching methods, developing the autonomy and the motivation of the learners, implementing and assessing learning outcomes of learners and so on) to enable the delivery of a role/job as technical and vocational teachers. However, General Psychology and Vocational Education are academic knowledge subjects with abstract and general concepts, rules and principles. Assessment tasks related to real-world and professional contexts are embedded into competence-based teaching methods such as problem-based learning, project-based learning, learning games, simulation, role - playing and dramatization etc. to provide students with good opportunities to develop problem-solving and presentation competences.

Based on the proposed process of integrating CBA into instruction Pedagogical subjects, assessment tasks were embedded in instruction General Psychology and Vocational Education subjects in the contents: 
Technical and Vocational Education Students at Ho Chi Minh City University of Technology and Education

Table 1. The integration CBA into instruction two subjects took into account in the contents

\begin{tabular}{|c|c|c|c|}
\hline No & General Psychology & No & Vocational Education \\
\hline 1 & The law of sensory threshold & 1 & Factors affecting personality development \\
\hline 2 & The nature of Thinking & 2 & Educational methods \\
\hline 3 & The basic logical thinking operations & & Technical and Vocational Teacher \\
\hline 4 & The laws of emotion & & \\
\hline 5 & The four-temperament theory & \\
\hline
\end{tabular}

There were 33 Food Technology Education students taking part in learning activities of the integration CBA into instruction General Psychology and 22 Garment Technology students with Vocational Education.

The period of time to implement this integration was from September to November belonging the first semester of the school year 2018 - 2019 at HCMUTE.

After identifying learning outcomes of each lesson, assessment tasks were designed to integrate into instruction for developing students' core competences. Before implementing the integration assessment tasks into teaching - learning activities, students were required to solve practical learning tasks and present their results in the class. The lecturer used the problem-solving competence and the presentation competence rubrics to identify initial core competences of students.

In the process of teaching, students were required to deal with assessment tasks of each lesson illustrated in the typical form, including essay, performance report, project, presentation etc. Individuals or groups identified and solved the tasks and then presented the result in the class.

The lecturer collected evidence on performance levels of students whilst and after they solved the assessment tasks and presented their results. Reports, posters, essay, plays, proposals etc. were typical evidence of solving the problem. Then, rubrics were used to score performance levels of students and made the judgments on students' problem-solving and presentation competences.

Each rubric comprises of criteria and performance levels. Criteria include the characteristics of problem-solving and presentation competences such as skills, knowledge. Problem-solving competence has five criteria, including identify the problem, collect and analyze relevant information, propose solutions, solve the problem, evaluate results. Presentation competence covers four criteria, including structure, contents, presentation, visual aid and time.

Performance levels are labels used to describe the levels of mastery tactfully but clearly. The rubric for problem-solving and presentation competences comprises of four performance levels: Exceed expectations; Meet expectations; Near expectations; and Below expectations.

The Problem- solving rubric was developed by Author's compilation to score performance levels of students as follows: 
Table 2. Problem-Solving Competence Rubric

\begin{tabular}{|c|c|c|c|c|c|}
\hline Criteria & Exceed Expectations (1) & Meet Expectations (2) & Below Expectations (3) & Not meet expectations(4) & Score \\
\hline Points & 10 & 8 & 5 & 0 & \\
\hline Identify the problem & Identify the problem accurately and fully & Identify the problem accurately & $\begin{array}{c}\text { Identify a half of the problem } \\
\text { accurately }\end{array}$ & Identify the problem wrongly & \\
\hline Collect and analyze information & $\begin{array}{l}\text { Collect information related to the } \\
\text { problem accurately and fully. } \\
\text { Analyze information related to } \\
\text { the problem accurately and fully. }\end{array}$ & $\begin{array}{l}\text { Collect information related to } \\
\text { the problem accurately. } \\
\text { Analyze information related } \\
\text { to the problem accurately. }\end{array}$ & $\begin{array}{l}\text { Collect information related to a } \\
\text { half of the problem accurately. } \\
\text { Analyze information related to } \\
\text { a half of the problem } \\
\text { accurately. }\end{array}$ & $\begin{array}{l}\text { - Collect information related } \\
\text { to the problem wrongly. } \\
\text { Analyze information } \\
\text { related to the problem } \\
\text { wrongly. }\end{array}$ & \\
\hline Propose solutions & $\begin{array}{l}\text { Propose solutions of solving the problem } \\
\text { scientifically and feasibly. }\end{array}$ & $\begin{array}{l}\text { Propose solutions of solving the } \\
\text { problem scientifically and feasibly. }\end{array}$ & $\begin{array}{l}\text { Propose solutions of solving the } \\
\text { problem scientifically but not feasibly. }\end{array}$ & $\begin{array}{c}\text { Do not propose solutions of } \\
\text { solving the problem. }\end{array}$ & \\
\hline Solve the problem & $\begin{array}{l}\text { Solve the problem accurately, logically } \\
\text { and fully. }\end{array}$ & Solve the problem accurately. & Solve a half of the problem accurately. & Solve the problem inaccurately. & \\
\hline Evaluate results & $\begin{array}{l}\text { - Give conclusions accurately, } \\
\text { broadly. } \\
\text { - Compare results with criteria. } \\
\text { - Propose suggestions for } \\
\text { improvements. }\end{array}$ & $\begin{array}{l}\text { - } \quad \text { Give conclusions accurately. } \\
\text { - } \quad \text { Compare results with criteria. }\end{array}$ & $\begin{array}{l}\text { - Give a half of conclusions } \\
\text { accurately. } \\
\text { Do not compare results with } \\
\text { criteria. }\end{array}$ & $\begin{array}{l}\text { - } \quad \text { Give conclusions wrongly. } \\
\text { Do not compare results } \\
\text { with criteria. }\end{array}$ & \\
\hline A. Total Possible Points & & & & & A \\
\hline $\begin{array}{l}\text { B. Total Number of Points } \\
\text { Received }\end{array}$ & & & & & B \\
\hline C. Total Score & & & & & $\mathrm{C}=\mathrm{B} / \mathrm{A}$ \\
\hline
\end{tabular}


One case of integrating CBA into instruction Vocational Education subject will be illustrated in the following: After completing the lesson "Educational methods", students will be able to apply education methods to solve real-world issues at vocational institutions. To achieve this learning outcome, groups of $4-6$ students were required to implement a mini project in one week: "Build three real-world issues at vocational institutions and apply educational methods to handle them".

With this task, each group built three real-world issues in vocational institutions and handled them by applying educational methods such as punishment, reward, competition, practice and so on. Results of building real-world issues and dealing with them were presented through typical formats, including plays, posters, reports etc. The lecturer and students co-assessed these results based on the rubrics. Performance levels of the problem-solving and presentation competences of students in each format were the clear evidence to identify whether their competences were improved or not.

In this case, the lecturer integrated the assessment task into instruction to provide students with opportunities to improve their competencies during the learning process. Findings of core competences of Food Technology Education and Garment Technology students will be fully analyzed as bellows:

\subsection{Core Competences of Food Technology Education Students before and after Integrating CBA into Instruction General Psychology Subject}

The integration CBA into instruction General
Psychology subject was conducted with 33 final year of students of the academic program of Food Technology Education at HCMUTE.

Assessment tasks are embedded into instruction General Psychology subject. Depending on the learning outcomes and the nature of each lesson, the lecturer selected and combined flexibly competence-based teaching methods with the assessment tasks. The results of dealing with these assessment tasks were rated based on the above rubrics.

\subsubsection{The First: Problem-Solving Competence of Food Technology Education Students}

The table 3 indicated that there was not any Food Technology Education student rated at the lowest level of Problem-solving competence before and after integrating CBA into instruction General Psychology subject. However, a significant difference between the initial Problem-solving competence and the Problem-solving competence of Food Technology students after integrating CBA into instruction General Psychology subject was found in this research. There were only 2 out of 33 students (at 6.1\%) achieved the level of "Exceed expectation" in the first measurement compared with the percentages of students possessing the similar level from $18.2 \%$ to $39.4 \%$ respectively after integrating CBA into instruction General Psychology subject. The most impressive point was a rapidly reduction even to $0 \%$ the proportion of students gaining the level of "Near Expectation" after conducting this integration into three out of five lessons in comparison with the previous period.

Table 3. Problem-Solving Competence of Food Technology Education students before and after integrating CBA into instruction General Psychology subject

\begin{tabular}{|c|c|c|c|c|c|c|c|c|c|}
\hline \multirow{3}{*}{ No } & \multirow{3}{*}{ Problem-Solving Competence } & \multicolumn{8}{|c|}{ Performance levels } \\
\hline & & \multicolumn{2}{|c|}{$\begin{array}{c}\text { Exceed } \\
\text { expectations }\end{array}$} & \multicolumn{2}{|c|}{$\begin{array}{c}\text { Meet } \\
\text { expectations }\end{array}$} & \multicolumn{2}{|c|}{$\begin{array}{c}\text { Near } \\
\text { expectations }\end{array}$} & \multicolumn{2}{|c|}{$\begin{array}{c}\text { Below } \\
\text { expectations }\end{array}$} \\
\hline & & $f$ & $\%$ & $f$ & $\%$ & $f$ & $\%$ & $f$ & $\%$ \\
\hline 1 & $\begin{array}{l}\text { Initial Problem-Solving Competence of Food Technology Education } \\
\text { students }\end{array}$ & 2 & 6.1 & 12 & 36.3 & 19 & 57.6 & 0 & 0 \\
\hline \multicolumn{10}{|c|}{ Problem-Solving Competence of Food Technology Education students after integrating CBA into Instruction General Psychology subject } \\
\hline 1 & $\begin{array}{l}\text { Problem-Solving Competence of Food Technology } \\
\text { Education students through dealing with the assessment task } \\
\text { of the lesson "The law of sensory threshold". }\end{array}$ & 6 & 18.2 & 27 & 81.8 & 0 & 0 & 0 & 0 \\
\hline 2 & $\begin{array}{l}\text { Problem-Solving Competence of Food Technology } \\
\text { Education students through dealing with the assessment task } \\
\text { of the lesson "The nature of Thinking" }\end{array}$ & 13 & 39.4 & 13 & 39.4 & 7 & 21.2 & 0 & 0 \\
\hline 3 & $\begin{array}{l}\text { Problem-Solving Competence of Food Technology } \\
\text { Education students through dealing with the assessment task } \\
\text { of the lesson "The basic logical thinking operations" }\end{array}$ & 7 & 21.2 & 20 & 60.6 & 6 & 18.2 & 0 & 0 \\
\hline 4 & $\begin{array}{l}\text { Problem-Solving Competence of Food Technology } \\
\text { Education students through dealing with the assessment task } \\
\text { of the lesson "The laws of emotion" }\end{array}$ & 12 & 36.4 & 21 & 63.6 & 0 & 0 & 0 & 0 \\
\hline 5 & $\begin{array}{l}\text { Problem-Solving Competence of Food Technology } \\
\text { Education students through dealing with the assessment task } \\
\text { of the lesson "The four-temperament theory" }\end{array}$ & 12 & 36.4 & 21 & 63.6 & 0 & 0 & 0 & 0 \\
\hline
\end{tabular}


On the other hand, the proportion of students possessed the levels of "Exceed expectation" and "Meet expectation" significantly increased simultaneously with the process of integrating CBA into instruction of each lesson. This finding revealed that providing students with meaningful opportunities to deal with assessment tasks engaged closely with real-world and professional contexts will enable them to improve gradually their own Problem-solving competence via experiencing and learning by doing.

\subsubsection{The Second: Presentation Competence of Food Technology Education Students}

Presentation is one of the most important competences of Pedagogical competences. Lack of the presentation competence, a Technical and Vocational Teacher will face difficulties to present, guide, organize a lesson as well as give and get feedback about the performance of students. As a result, forming and developing this competence of Technical and Vocational Students need be done regularly during the entire teaching process.

This paper proposed criteria of presentation competence, including structure, contents, presentation, visual aid and time. The integration CBA into instruction Pedagogical subjects require students to present their results in the class after solving the assessment tasks. This activity gives students good chances to practice continuously the criteria of the presentation competence such as designing the structure; collecting and analyzing the content, making presentation, using visual aids and managing time. Findings of the presentation competence of Food
Technology Education students before and after integrating CBA into instruction General Psychology subject is presented in the table 4 .

It is clear that the proportion of students achieved the levels of "Exceed expectation" and "Meet expectation" after presenting the result of dealing with the assessment task of four out of five lessons going up considerably in comparison with the previous period. However, not any student obtained the highest performance level of the presentation competence after completing the lesson of "The nature of thinking". There was a significant increase of the number of students gaining the level "Meet expectation" and reduced over a half of the number of students at the level of "Near expectation" in the same lesson compared with the first measurement.

Linking the figures of the presentation competence with the Problem-solving competence revealed that there was not too much difference about the percentage of students possessing the level of "Near expectation" of the presentation competence (at 18.2\%) and the Problem-solving competence (at $21.2 \%$ ) when CBA was immersed into Instruction the lesson "The nature of thinking". This finding might be explained that the assessment task of the lesson is too difficult to deal, and the lesson covers too much academic knowledge that students cope with difficulties to present. If this explanation was precise, the assessment task should be redesigned to be relevant to students' ability. On the other hand, academic knowledge needs to be presented and explained clearly to avoid misunderstanding and interpreting incorrectly.

Table 4. Presentation Competence of Food Technology Education students before and after integrating CBA into instruction General Psychology subject

\begin{tabular}{|c|c|c|c|c|c|c|c|c|c|}
\hline \multirow{3}{*}{ No } & \multirow{3}{*}{ Presentation Competence } & \multicolumn{8}{|c|}{ Performance levels } \\
\hline & & \multicolumn{2}{|c|}{$\begin{array}{c}\text { Exceed } \\
\text { expectations }\end{array}$} & \multicolumn{2}{|c|}{$\begin{array}{c}\text { Meet } \\
\text { expectations }\end{array}$} & \multicolumn{2}{|c|}{$\begin{array}{c}\text { Near } \\
\text { expectations }\end{array}$} & \multicolumn{2}{|c|}{$\begin{array}{c}\text { Below } \\
\text { expectations }\end{array}$} \\
\hline & & $f$ & $\%$ & $f$ & $\%$ & $f$ & $\%$ & $f$ & $\%$ \\
\hline 1 & $\begin{array}{l}\text { Initial Presentation Competence of Food Technology Education } \\
\text { students }\end{array}$ & 5 & 15.2 & 18 & 54.5 & 10 & 30.3 & 0 & 0 \\
\hline \multicolumn{10}{|c|}{ Presentation of Food Technology Education students after integrating CBA into Instruction General Psychology subject } \\
\hline 1 & $\begin{array}{l}\text { Presentation Competence of Food Technology Education } \\
\text { students through presenting the result of dealing with the } \\
\text { assessment task of the lesson "The law of sensory threshold". }\end{array}$ & 6 & 18.2 & 27 & 81.8 & 0 & 0 & 0 & 0 \\
\hline 2 & $\begin{array}{l}\text { Presentation Competence of Food Technology Education } \\
\text { students through presenting the result of dealing with the } \\
\text { assessment task of the lesson "The nature of Thinking" }\end{array}$ & 0 & 0 & 27 & 81.8 & 6 & 18.2 & 0 & 0 \\
\hline 3 & $\begin{array}{l}\text { Presentation Competence of Food Technology Education } \\
\text { students through presenting the result of dealing with the } \\
\text { assessment task of the lesson "The basic logical thinking } \\
\text { operations" }\end{array}$ & 7 & 21.2 & 26 & 78.8 & 0 & 0 & 0 & 0 \\
\hline 4 & $\begin{array}{l}\text { Presentation Competence of Food Technology Education } \\
\text { students through presenting the result of dealing with the } \\
\text { assessment task of the lesson "The laws of emotion" }\end{array}$ & 12 & 36.4 & 21 & 63.6 & 0 & 0 & 0 & 0 \\
\hline 5 & $\begin{array}{l}\text { Presentation Competence of Food Technology Education } \\
\text { students through presenting the result of dealing with the } \\
\text { assessment task of the lesson "The four-temperament theory" }\end{array}$ & 18 & 54.5 & 15 & 45.5 & 0 & 0 & 0 & 0 \\
\hline
\end{tabular}


In brief, the figures for the improvement of Problem-Solving and presentation competences of Food Technology Education students from the level of "Near expectation" to "Meet expectation" and "Exceed expectation" climbed up significantly after integrating CBA into instruction General Psychology subject at HCMUTE.

\subsection{Core Competences of Garment Technology Education Students before and after Integrating CBA into Instruction Vocational Education Subject}

To more deeply study on the influence of integrating CBA into instruction on the improvement the Problem-solving competence and the presentation competence of Technical and Vocational students, this research continued to be carried out with Vocational Education subject. There was 22 final year of students of the academic program of Garment Technology Education at HCMUTE participating in activities of this integration in the first semester of the school year 2018 - 2019 at HCMUT.

\subsubsection{The First: Problem-Solving Competence of Garment Technology Education Students}

Vocational Education subjects give students academic knowledge related to personality and personality development, education methods, technical and vocational teachers and their personality. Lecturing and Socratic Dialogue are typical teaching methods to deliver these academic knowledge to students in the KBE. These methods seem to concentrate on students' remembering and understanding. Thus, the integration CBA into various competence - based teaching - learning activities provides students with opportunities to improve their competences by applying academic knowledge to solve the assessment associated with real-world and professional contexts.

The table 5 gives information about the Problem-solving competence of Garment Technology Education students before and after implementing CBA into instruction Vocational Education subject. Overall, there was a sharp improvement about the performance levels of the Problem-solving competence of students. Not any student attained the level "Near expectation" in all three lessons in comparison with 10 out of 22 students (at $45.5 \%$ ) of the previous period. Furthermore, nearly $41 \%$ up to $72.7 \%$ students kept obtaining the level "Meet expectation" after solving the assessment tasks.

In addition, the rate of students got the highest performance level of this competence growing steeply through dealing with the assessment tasks of the lesson "Education methods" (at 59.1\%) and "Factors affecting personality development" (at 50\%). There was a significant rise about this same level through the lesson "Technical and Vocational Teacher" at $27.3 \%$ compared with $4.5 \%$ in the first scoring.

Table 5. Problem-Solving Competence of Garment Technology Education students before and after integrating CBA into instruction Vocational Education subject

\begin{tabular}{|c|c|c|c|c|c|c|c|c|c|}
\hline \multirow{3}{*}{ No } & \multirow{3}{*}{ Problem-Solving Competence } & \multicolumn{8}{|c|}{ Performance levels } \\
\hline & & \multicolumn{2}{|c|}{$\begin{array}{c}\text { Exceed } \\
\text { expectations }\end{array}$} & \multicolumn{2}{|c|}{$\begin{array}{c}\text { Meet } \\
\text { expectations }\end{array}$} & \multicolumn{2}{|c|}{$\begin{array}{c}\text { Near } \\
\text { expectations }\end{array}$} & \multicolumn{2}{|c|}{$\begin{array}{c}\text { Below } \\
\text { expectations }\end{array}$} \\
\hline & & $f$ & $\%$ & $f$ & $\%$ & $f$ & $\%$ & $f$ & $\%$ \\
\hline 1 & $\begin{array}{l}\text { Initial Problem-Solving Competence of Garment Technology } \\
\text { Education students }\end{array}$ & 1 & 4.5 & 11 & 50.0 & 10 & 45.5 & 0 & 0 \\
\hline \multicolumn{10}{|c|}{ Problem-Solving Competence of Garment Technology Education students after integrating CBA into Instruction General Psychology subject } \\
\hline 1 & $\begin{array}{l}\text { Problem-Solving Competence of Garment Technology } \\
\text { Education students through dealing with the assessment task } \\
\text { of the lesson "Factors affecting personality development". }\end{array}$ & 11 & 50.0 & 11 & 50.0 & 0 & 0 & 0 & 0 \\
\hline 2 & $\begin{array}{l}\text { Problem-Solving Competence of Garment Technology } \\
\text { Education students through dealing with the assessment task } \\
\text { of the lesson "Educational methods" }\end{array}$ & 13 & 59.1 & 9 & 40.9 & 0 & 0 & 0 & 0 \\
\hline 3 & $\begin{array}{l}\text { Problem-Solving Competence of Garment Technology } \\
\text { Education students through dealing with the assessment task } \\
\text { of the lesson "Technical and Vocational Teacher" }\end{array}$ & 6 & 27.3 & 16 & 72.7 & 0 & 0 & 0 & 0 \\
\hline
\end{tabular}


Table 6. Presentation Competence of Garment Technology Education students before and after integrating CBA into instruction Vocational subject

\begin{tabular}{|c|c|c|c|c|c|c|c|c|c|}
\hline \multirow{3}{*}{ No } & \multirow{3}{*}{ Presentation Competence } & \multicolumn{8}{|c|}{ Performance levels } \\
\hline & & \multicolumn{2}{|c|}{$\begin{array}{c}\text { Exceed } \\
\text { expectations }\end{array}$} & \multicolumn{2}{|c|}{$\begin{array}{c}\text { Meet } \\
\text { expectations }\end{array}$} & \multicolumn{2}{|c|}{$\begin{array}{c}\text { Near } \\
\text { expectations }\end{array}$} & \multicolumn{2}{|c|}{$\begin{array}{c}\text { Below } \\
\text { expectations }\end{array}$} \\
\hline & & $f$ & $\%$ & $f$ & $\%$ & $f$ & $\%$ & $f$ & $\%$ \\
\hline 1 & $\begin{array}{l}\text { Initial Presentation Competence of Garment Technology Education } \\
\text { students }\end{array}$ & 3 & 13.6 & 9 & 40.1 & 10 & 45.5 & 0 & 0 \\
\hline \multicolumn{10}{|c|}{ Presentation Competence of Garment Technology Education students after integrating CBA into Instruction General Psychology subject } \\
\hline 1 & $\begin{array}{l}\text { Presentation Competence of Garment Technology Education } \\
\text { students through presenting the result of dealing with the } \\
\text { assessment task of the lesson "Factors affecting personality } \\
\text { development". }\end{array}$ & 17 & 72.3 & 5 & 22.7 & 0 & 0 & 0 & 0 \\
\hline 2 & $\begin{array}{l}\text { Presentation Competence of Garment Technology Education } \\
\text { students through presenting the result of dealing with the } \\
\text { assessment task of the lesson "Educational methods" }\end{array}$ & 18 & 81.8 & 4 & 18.1 & 0 & 0 & 0 & 0 \\
\hline 3 & $\begin{array}{l}\text { Presentation Competence of Garment Technology Education } \\
\text { students through presenting the result of dealing with the } \\
\text { assessment task of the lesson "Technical and Vocational } \\
\text { Teacher" }\end{array}$ & 14 & 63.6 & 8 & 36.4 & 0 & 0 & 0 & 0 \\
\hline
\end{tabular}

\subsubsection{The Second: Presentation Competence of Garment Technology Education Students}

The table 6 illustrates some changes to the improvement of the presentation competence of Garment Technology Education students after integrating CBA into instruction Vocational Education subject in comparison with the previous period. Overall, there was a dramatically increase of the highest level of the presentation competence in all three lessons. Almost students achieved this level after presenting the results of handling the assessment tasks compared with the small number of students in the first scoring.

It is a little bit interesting to find that there was not a sharply difference about the proportion of students getting the level "Meet expectation", whereas the figure for the level "Near expectation" went down by $45.5 \%$ (from $45.5 \%$ to $0 \%$ ) before and after implementing this integration. In the other word, none of students possessed this level of the presentation competence after presenting the results of dealing with the assessment tasks of Vocational Education subject.

A hypothetical explanation for the sharply improvement of the Problem-Solving competence and the presentation competence of Garment Technology Education students when CBA was embedded into instruction Vocational Education subject is that the assessment tasks raise learning motivation and are suitable with students' ability. Otherwise, they are so flexibly embedded into various teaching-learning activities that students become more gradually familiar with ways of dealing and presenting. If the hypothetical explanation were exact, the integration CBA into instruction Vocational Education subject would be conducted and expanded broadly in other pedagogical subjects to improve holistic competences of students.

In conclusion, based on the proposed process of integrating CBA into instruction Pedagogical subjects, the lecturer conducted it with General Psychology and
Vocational Education subjects at HCMUTE. Findings revealed that there was the significant improvement about the Problem-solving competence and the presentation competence of Garment and Food Technology Education students. The percentages of students attained the performance levels of "Exceed expectation" and "Meet expectation" going up more sharply after dealing with the assessment tasks and presenting the results during five lessons of General Psychology and three lessons of Vocational Education subjects. These initial findings illustrated clearly the influence of the integration CBA into instruction Pedagogical subjects on the improvement of these core competences of Technical and Vocational Education students.

\section{Conclusions}

With the tendency of shifting from Knowledge-Based Education into Competence-Based Education, assessment is not only of learning but also for and as learning. Although instruction and assessment are key components of the teaching process, but they are considerable separated from each other in the Knowledge-Based Education.

In Competence-Based Education, CBA is the process of collecting evidence and making judgments on whether competence has been achieved as well as regulates teaching and learning activities. The integration CBA into instruction gives students opportunities to apply academic knowledge to deal with assessment tasks related to the real-world contexts and enable them to hands-on and experience to self-construct their competences.

The integration CBA into instruction Vocational Education and General Psychology subjects brought encouraging findings to the improvement of the Problem-solving competence and the presentation competence of 33 Food Technology Education and 22 Garment Technology Education students at HCMUTE. To 
develop pedagogical and core competences of Technical and Vocational students, some minor suggestions should be done in the following:

- Redesign the Knowledge-Based Academic Program into Competence-Base Academic Program.

- Design a variety of assessment tasks relating to applying academic knowledge to handle real-world issues. Competence-Based Assessment tasks should be various, including essay, performance report, project, presentation, poster, self-assessment, peer-assessment etc.

- Assessment tasks are constructively aligned with the course learning outcomes, teaching and learning activities.

- Combine a diverse of Competence-Based Teaching methods such as problem-based learning, project-based learning, learning games, simulation, role - playing and dramatization etc. in every lesson of Pedagogical subjects.

- Assessment tools should be designed carefully to measure students' competences precisely, fairly and reliably.

\section{REFERENCES}

[1] Cees P.M. van der Vleuten. (2015). Competency-based education is beneficial for professional development. Perspectives on Medical Education. Volume 4, Issue 6, December 2015. Online: https://link.springer.com/content/ pdf/10.1007\%2Fs40037-015-0232-6.pdf

[2] Wolf, A. (1995). Competence based assessment. Open University Press. Buckingham, Philadelphia.

[3] Department of Training and Workforce Development, Western Australia (2013). Guidelines for assessing competence in VET [5th edition]. Online: https://www.voc ed.edu.au/content/ngv\%3A65912

[4] Duong, T. K. O. (2016). Developing core competencies of students through Competence Based Assessment at Ho Chi Minh City University of Technology and Education. TVET@Asia, issue 7, 1-17. Online: http://www.tvet-onlin e.asia/issue7/duong_tvet7.pdf

[5] William, D. (2004). Keeping learning on track: integrating assessment with instruction. The International Association for Educational Assessment (IAEA) held in June 2004, Philadelphia, PA. Online: http://www.dylanwiliam.org/Dyl an_Wiliams_website/Papers_files/IAEA\%2004\%20paper. pdf

[6] Oosterhof, A. (2003). Developing and Using Classroom Assessment (3rd Edition). Upper Saddle River, New Jersey: Pearson.

[7] Sesutho Koketso Kesianye (2015). The three perspectives of integration assessment and instruction in the learning school mathematics. Journal of Education and Practice. ISSN 2222-1735 (Paper) or ISSN 2222-288X (Online). Vol.6, No.19, 2015. Online: https://files.eric.ed.gov/fulltex

\section{t/EJ1079550.pdf}

[8] Elui, E. P. (2008). Integrating assessment into the lesson plan to improve learning: A focus on Nigerian Primary Schools. The 35th conference of the international association for educational assessment. Cambridge University, England. 7th - 12th September 2008.Online: https://iaea.info/documents/integrating-assessment-into-the -lesson-plan-to-improve-learning-a-focus-on-nigerian-prim ary-schools/

[9] $\mathrm{M}^{\mathrm{a}}$ Asunción Romero López. (2016). European Higher Education Area-Driven Educational Innovation. Procedia Social and Behavioral Sciences 237 (2017) 1505 - 1512. Online: https://doi.org/10.1016/j.sbspro.2017.02.237 